\title{
Energy conservation by retrofitting of dwellings
}

\author{
Imrich Sánka ${ }^{1, *}$ and Dušan Petráš ${ }^{1}$ \\ ${ }^{1}$ Slovak University of Technology in Bratislava, Faculty of Civil Engineering, Radlinksého 11, 81005 Bratislava
}

\begin{abstract}
This article investigates the impact of energy renovation on the indoor environmental quality of apartment building during heating season. The study was performed in one residential building before and after its renovation. Energy auditing and classification of the selected building into energy classes were carried out. Additionally, evaluation of indoor air quality was performed using objective measurements and subjective survey. Thermal environment and concentration of $\mathrm{CO}_{2}$ was measured in bedrooms. Higher concentrations of $\mathrm{CO}_{2}$ was observed in the residential building after its renovation. The concentrations of $\mathrm{CO}_{2}$, in some cases exceeded the recommended maximum limits, especially after implementing of energy saving measures on the building. The average air exchange rate was visible higher before renovation of the building. The current study indicates that large-scale of renovations may reduce the quality of the indoor environment in many apartments, especially in the winter season.
\end{abstract}

\section{Intorduction}

Most of the residential buildings in Slovakia that were built in the 20th century do not satisfy the current requirements for energy efficiency presented in the national building code. Nationwide remedial measures have been taken to improve the energy efficiency of these buildings and reduce their energy use [2]. However, since the impact of these measures on indoor air quality is rarely considered, they often compromise indoor air quality due to the decreased ventilation and infiltration rate.

The highest development in the housing stock, as a result of economic changes and population growth, was recognized during the second half of the 20th century [1].

The majority of housing in Central and Eastern Europe was constructed from panel technology. The degradation of its quality which has led to its renovation, has become one of the most important measures from an energysaving point of view.

The aim of the study was to evaluate the impact of basic energy-saving measures on energy demand of the building and indoor air quality in a typical high-rise residential building built in the 1960s in Slovakia.

\section{Building description}

The residential building investigated (Figure 1.) is located in Šamorín, Slovakia. It was built in 1964 from lightweight concrete panels. The building was naturally ventilated. Exhaust ventilation was only used in sanitary rooms, such as the bathrooms and toilets. Renovation of the building was carried out in 2015 and included the following measures: insulation of the building envelope using polyethylene $(80 \mathrm{~mm})$, insulation of the roof using mineral wool $(120 \mathrm{~mm})$ and hydraulic balancing of the heating system. New plastic frame windows had already been installed in recent over the last years in most of the apartments in the building. [3]
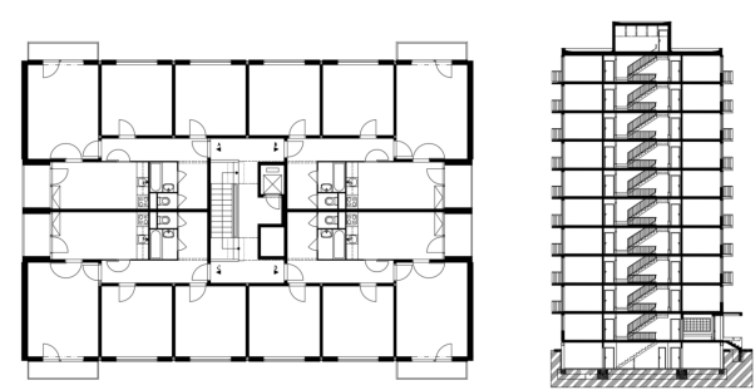

Fig. 1. Floor plan and cross section of the evaluated building
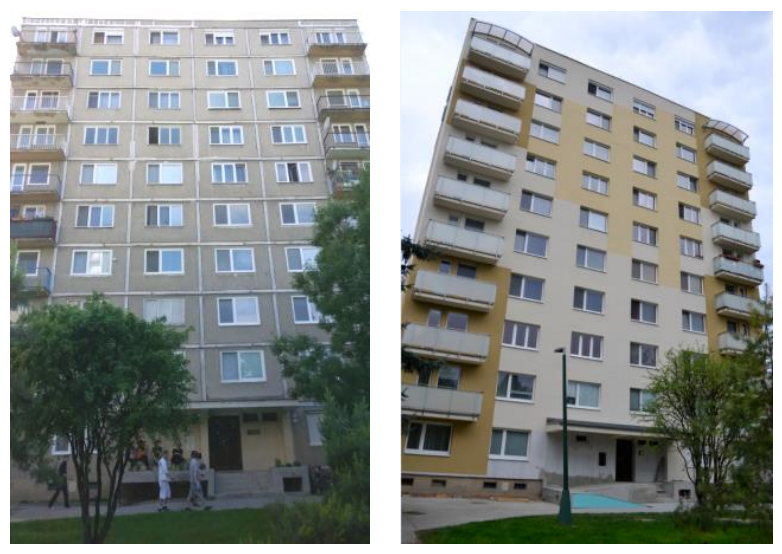

Fig. 2. The evaluated dwelling before and after refurbishment

\footnotetext{
* Corresponding author: imrich.sanka@gmail.com
} 


\section{Energy demand}

The heat demand was calculated for the non-renovated and renovated condition. The highest energy-saving is provided by the thermal insulation of the external walls. This can be explained with the large heat exchange surface of the walls.

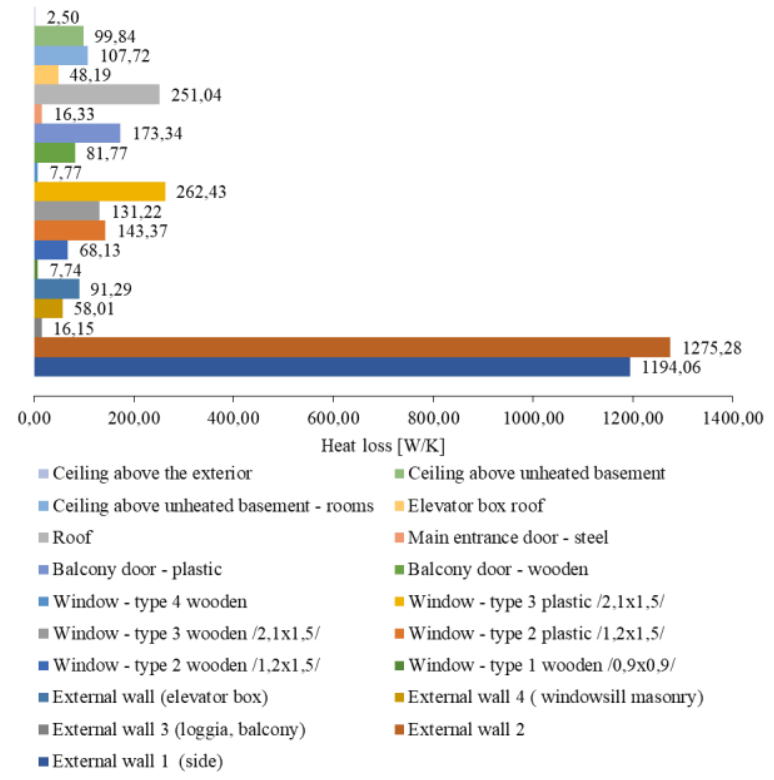

Fig. 3. Heat losses- renovated condition

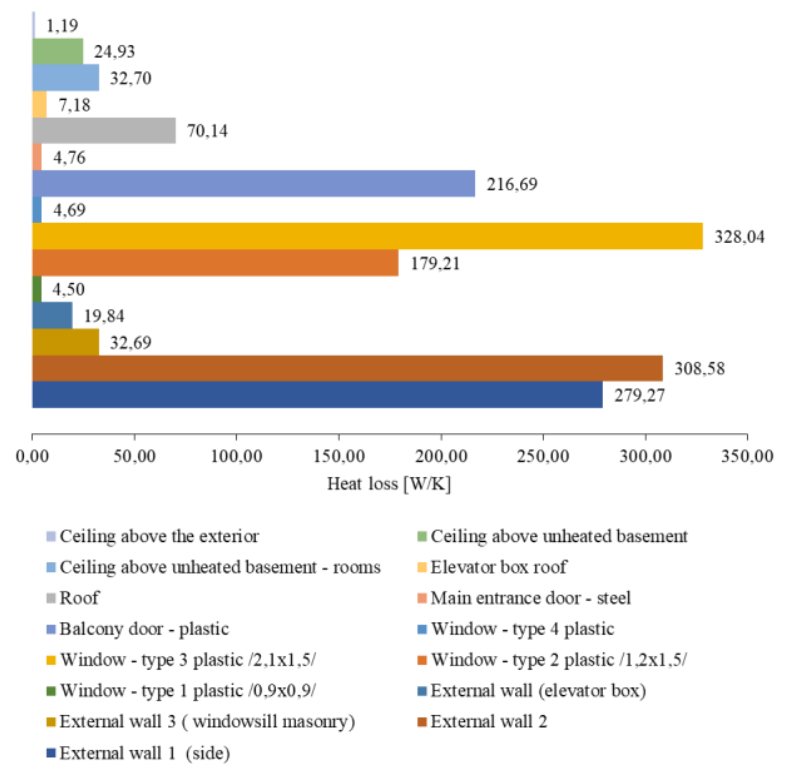

Fig. 4. Heat losses - renovated condition

On the Figure 2. and Figure 3. is clearly indicated the heat demand for the structures for square meter and the solar and heat gains for both types of residential building. The figure shows that the heat demand for the insulated part of the building significantly decreased and for the calculated infiltration and gains remained approximately the same.

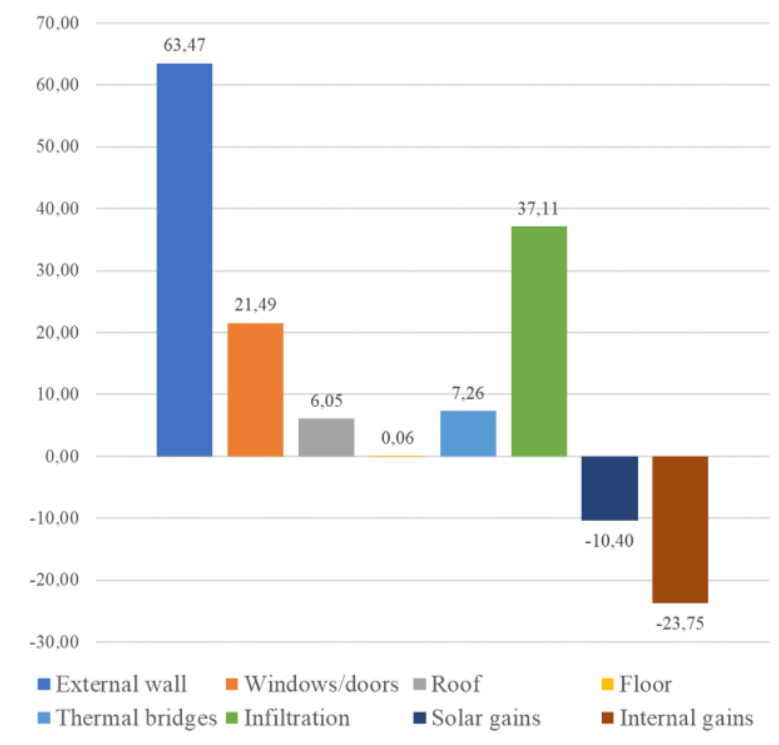

Fig. 5. Heat demand by the structures - non-renovated condition

A minimal change is noticeable on Figure 5 and 6 . between solar gains. This can be explained by the difference in the solar transmittance coefficient in the replaced transparent structures.

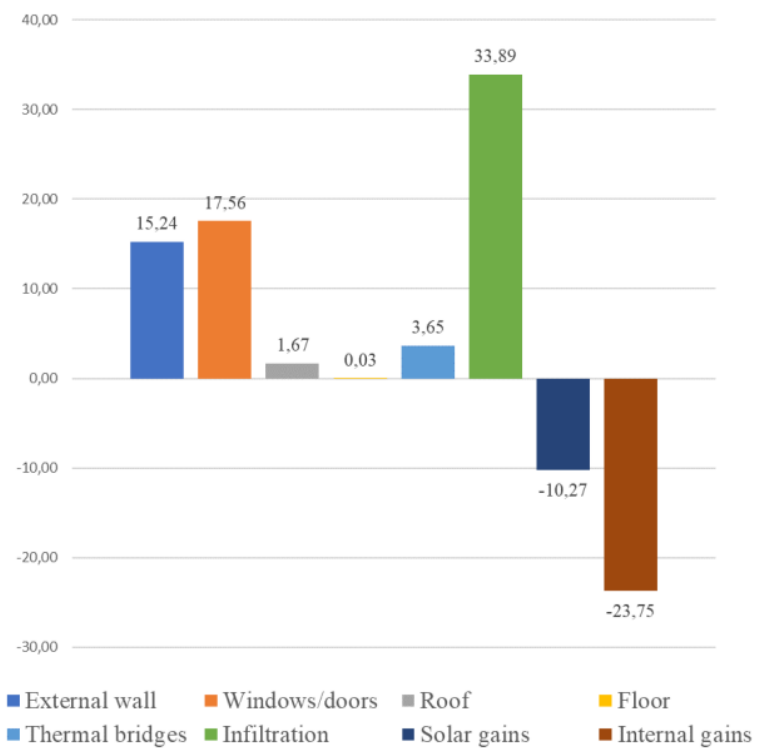

Fig. 6. Heat demand by the structures - renovated condition

\section{Methodology}

The first round of the energy consumption and air quality measurements was performed in January 2015 when the building was still in its original condition. The second round was performed in January 2016 after energy saving-measures had been implemented. Twenty apartments were selected across the residential building; they were equally distributed on the lower, middle and highest storeys of the building. The same apartments 
were investigated in both winter seasons over a period of eight days [4][5].

\subsection{Energy consumption}

Energy consumption was measured in heat exchanger station, e.g. heat meter, gas meter, water meter, electricity meter.
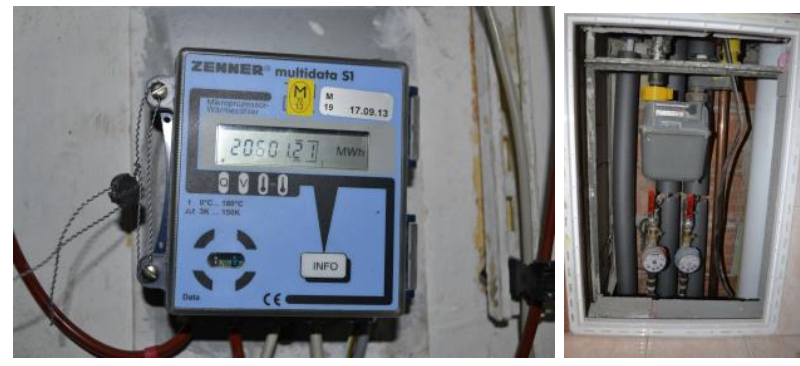

Fig. 6. Energy consumption measuring

All the measured values had been related to the whole apartment building.

\subsection{Indoor air quality}

The temperature, relative humidity and $\mathrm{CO}_{2}$ concentration, were measured in the bedrooms of the apartments. HOBO U12-012 data loggers and CARBOCAP $\mathrm{CO}_{2}$ monitors (Figure 4) were used for recording the temperature and $\mathrm{CO}_{2}$ concentration data.

Each unit was placed at a sufficient distance from the windows and beds to minimize the effect of the incoming fresh air or the effect of the sleeping occupants. The space between the furniture and the rooms corners was avoided. The $\mathrm{CO}_{2}$ concentration was used to calculate the air exchange rate over eight nights in each bedroom. The occupants $\mathrm{CO}_{2}$ emission rate was determined from their weight and height as set out in questionnaires [3][4][5].

\section{Results}

In this section the indoor air quality analysis and the energy evaluation results are presented.

\subsection{Energy efficiency}

The energy-saving measures mentioned above decreesd the energy consumption by $55 \%$. In accordance to our law on energy efficiency of buildings, the original dwelling belonged to the „E“ category $(159 \mathrm{kWh} / \mathrm{m} 2 \mathrm{a})$, after refurbishment to the „B“" category $(74 \mathrm{kWh} / \mathrm{m} 2 \mathrm{a})$.

The renovated and non-renovated residential building were classified into energy classes by the valid Slovak legislation: Decree of the Ministry of Transport, Construction and Regional Development No: 300/2012.

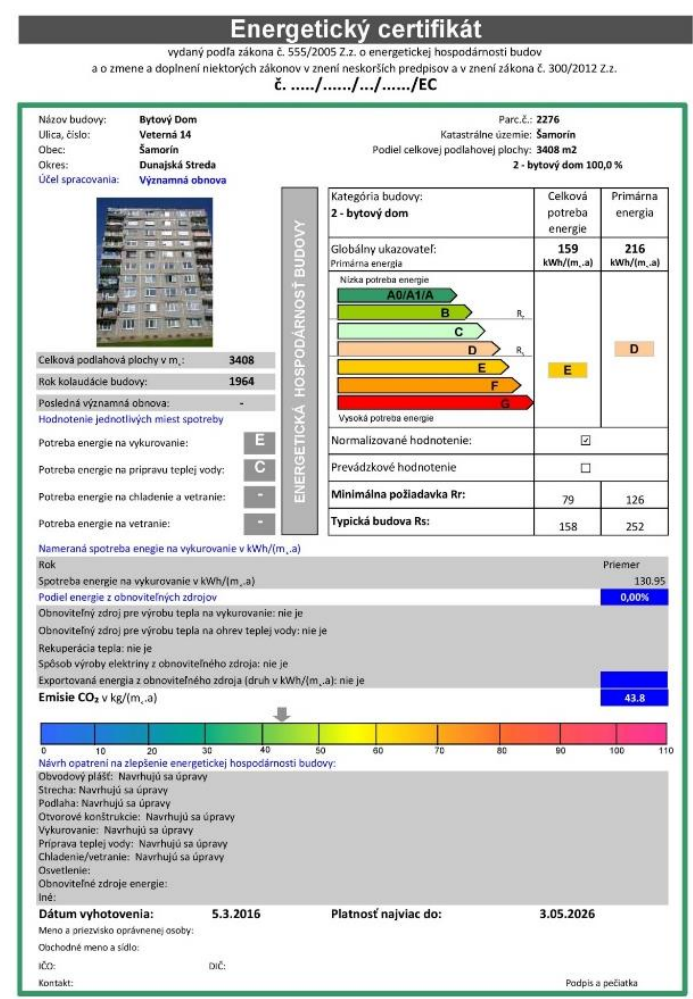

Fig. 7. Energy Certificate of the non-renovated building $[10][11]$

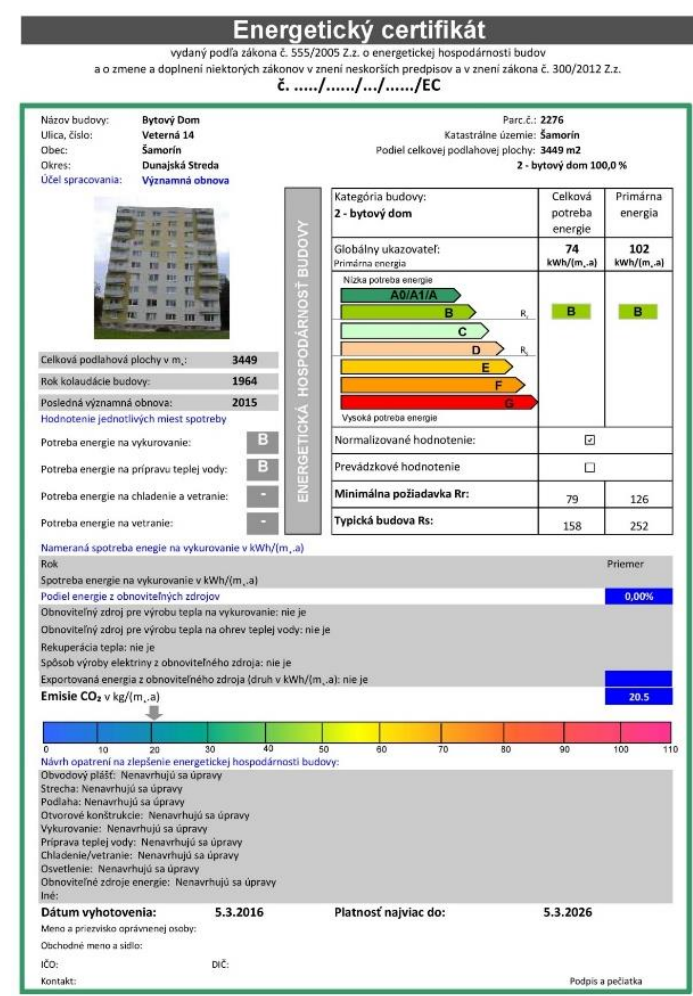

Fig. 8. Energy Certificate of the renovated building [10][11] 


\subsection{Indoor air quality results}

The $\mathrm{CO}_{2}$ concentrations before and after the renovation of the building are shown in Figure 9. Most of the $\mathrm{CO}_{2}$ concentration data points were within the acceptable limit (green line) before the renovation (blue line), while significantly higher concentrations were measured after the renovation (red line). Table 1 present the descriptive statistics of the day and night-time $\mathrm{CO}_{2}$ concentrations before and after the renovation of the residential building. The grand average was $1205 \mathrm{ppm}$ and the median was $1190 \mathrm{ppm}$ before the renovation.

After implementing the energy-saving measures, the $\mathrm{CO}_{2}$ concentration visibly increased. The mean was 1570 ppm and the median was $1510 \mathrm{ppm}$.

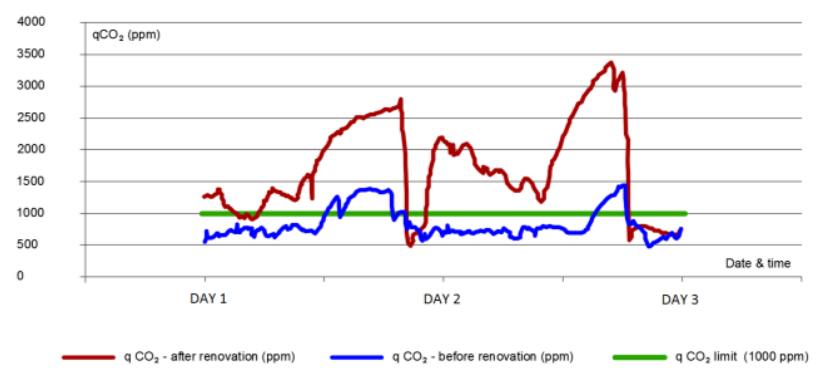

Fig. 9. Example of $\mathrm{CO} 2$ concentration in one selected apartment during two days out of the whole measurement period before and after renovation. [10] [11]

Table 1: Day- and night-time $\mathrm{CO} 2$ concentration before and after renovation

a) Before renovation $(\mathrm{N}=20)$

\begin{tabular}{|l|l|l|l|l|}
\hline \multirow{2}{*}{ Time period } & CO2 $(\mathrm{ppm})$ & \multicolumn{4}{|l|}{} \\
\cline { 2 - 5 } & Average & Minimum & Maximum & Median \\
\hline Day & 1040 & 595 & 1550 & 1030 \\
\hline Night & 1400 & 740 & 2665 & 1300 \\
\hline Whole period & 1205 & 660 & 2050 & 1190 \\
\hline
\end{tabular}

b) After renovation (N=20)
\begin{tabular}{|l|l|l|l|l|}
\hline \multirow{2}{*}{ Time period } & \multicolumn{4}{l}{ CO2 $(\mathrm{ppm})$} \\
\cline { 2 - 5 } & Average & Minimum & Maximum & Median \\
\hline Day & 1320 & 790 & 2210 & 1265 \\
\hline Night & 1925 & 865 & 3575 & 1825 \\
\hline Whole period & 1570 & 870 & 2770 & 1510 \\
\hline
\end{tabular}

The lower $\mathrm{CO}_{2}$ concentration before the renovation resulted in higher AERs in the apartments (average 0.61 $\mathrm{h}-1)$. After the renovation, the mean air exchange rate (0.44 h-1) dropped below the recommended minimum (0.5 h-1) (Table 2).

Table 2: AER before and after renovation [10][11]

\begin{tabular}{|l|l|l|l|l|}
\hline AER & Average & Minimum & Maximum & Median \\
\hline $\begin{array}{l}\text { Before renovation } \\
(\mathrm{N}=20)\end{array}$ & 0,61 & 0,32 & 1,15 & 0,59 \\
\hline $\begin{array}{l}\text { After renovation } \\
(\mathrm{N}=20)\end{array}$ & 0,44 & 0,21 & 0,76 & 0,45 \\
\hline
\end{tabular}

\section{Discussion}

Many international studies have also attributed this phenomenon to the fact that older buildings are leakier and newer ones are more air-tight as a result of improved construction techniques and stricter regulations [8][9]. The limitation of the study is its small sample size. The validation of the results on a larger sample size is warranted.

The findings presented in this measurement campaign further support the conclusions of previous studies in Slovakia [2][3][4] that deterioration of indoor air quality follows energy renovations. In this study the implementation of the energy-saving measures was not combined with measures to improve the indoor environmental quality, which explains the lower AERs and higher $\mathrm{CO} 2$ concentrations in the renovated buildings in the winter season.

\section{Conclusion}

A key goal of the implementation of an energy renovation strategy is to achieve the improved energy efficiency of buildings. However, the effect of these programs has not been systematically assessed. The effects on indoor air quality and well-being of the occupants is often ignored. There is an urgent need to assess the impact of the currently applied building renovation practices on the residential indoor air quality on a nationwide scale.

\section{Acknowledgement}

This work was supported by the Slovak Research and Development Agency under the Contract No. DS-20160030, and by the Ministry of Education, Science, Research and Sport under VEGA Grants 1/0807/17 and $1 / 0847 / 18$.

\section{References}

1. Jurelionis A., Seduikyte L. (2010) Assessment of indoor climate conditions in multifamily buildings in Lithuania before and after renovation. 2nd International conference advanced construction. Kaunas, Lithuania.

2. Földváry V., Bekö G., Petráš D. (2014) Impact of energy renovation on indoor air quality in multifamily dwellings in Slovakia. Proceedings of Indoor Air 2014, Hong Kong, Paper No. HP0143. Arash Rasooli, Laure Itard, Carlos Infante Ferreira, "Rapid, transient, in-situ determination of wall's thermal transmittance," in Rehva Journal, vol. 5, 2016, pp16-20.

3. Földváry V., Bekö G., Petráš D. (2015) Seasonal variation in indoor environmental quality in nonrenovated and renovated multifamily dwellings in Slovakia. Proceedings of Healthy Buildings Europe 2015, Eindhoven, Paper ID 242. 
4. Földváry V. (2016) Assessment of indoor environmental quality in residential buildings before and after renovation. Doctoral thesis. Bratislava, Slovakia.

5. Bekö G., Földváry V., Langer S., Arrhenius K. (2016) Indoor air quality in a multifamily apartment building before and after energy renovation. Proceedings of the 5th International Conference on Human-Environment System, ICHES 2016 Nagoya, Japan.

6. Persily A. K. (1997) Evaluating Building IAQ and Ventilation with Indoor Carbon Dioxide. ASHRAE Transactions. 103, Vol. 2.

7. N. Klepeis, W. C. Nelson, W. R. Ott el al. The National Human Activity Pattern Survey (NHAPS): a resource for assessing exposure to environmental pollutants. Journal of Exposure Analysis and Environmental Epidemiology. 11, 2001, pp. 231-252.

8. Kotol M., Rode C., Clausen G., Nielsen T. R. (2014) Indoor environment in bedrooms in 79 Greenlandic households, Building and Environment, Vol. 81, pp. 29-36.

9. Bekö G., Toftum J., Clausen G. (2011) Modelling ventilation rates in bedrooms based on building characteristics and occupant behaviour. Building and Environment, Vol 46, pp. 2230-2237.

10. Sánka I., Földváry V., Petráš D. (2016) Experimentálne meranie CO2 a intenzity výmeny vzduchu v bytovom dome. TZB-Haustechnik, Vol 25, pp. 46-49.

11. Sánka I., Földváry V., Petráš D. (2017) Evaluation of Indoor Environment Parameters in a Dwelling before and after renovation. Magyar épűletgépészet Vol, 65, pp. 29-33.

12. Sánka I., Földváry V., Petráš D. (2017) Experimentálne meranie toxických látok vo vnútornom vzduchu pred a po obnove bytového domu. TZB-Haustechnik, Vol 26. 2/2017, pp. 3235 